\title{
DETERMINANTS OF DECISION FOR NON-FARM ENTREPRENEURSHIP BY WOMEN FARMERS IN IKWUANO LGA, ABIA STATE
}

\author{
Osondu, Charles Kelechi \\ Department of Agricultural Economics and Extension, Abia State University, Umuahia Campus, \\ PMB 7010, Umuahia, Abia State, Nigeria. \\ *E-mail for correspondence: osonducharles87@gmail.com
}

\begin{abstract}
Recent years have witnessed numerous Government efforts to boost agricultural production in Nigeria. A key input to achieve this is credit. In the face of formal credit acquisition bottlenecks, there is the need to shift attention to non-farm entrepreneurship, as income made in this sector could be invested in agriculture. This study therefore evaluated determinants of decision for nonfarm entrepreneurship by women farmers in Ikwuano Local Government Area of Abia State. The specific objectives of the study were to: describe the socio-economic characteristics of women farmers engaged in non-farm enterprise in the study area; determine factors that influence women decision to embark on non-farm enterprise in the study area; and identify problems constraining women from embarking on non-farm enterprise in the study area. A hree stage random sampling technique was adopted in the selection of 120 respondents for the study. Analytical tools utilized, were frequency distribution tables, percentages, means and probit regression model. The probit regression analysis revealed that age, household size, primary occupation, farm income, access to credit, farming experience and membership of cooperative societies were significant determinants of women farmers decision to embark on non-farm enterprise at varied signs and levels of significance. The women were constrained from embarking on non-farm business by lack of startup capital (43.33\%), inadequate credit access (35.00), and land procurement barriers (31.67). In line with the findings of the study, it was recommended that the Land Use Act of 1978 should be fully implemented as it will ameliorate the persistent land procurement problem faced by women farmers in Nigeria.
\end{abstract}

Key Words: Decision Determinant, Non-farm Entrepreneurship, Income Generation.

\section{INTRODUCTION}

Due to rapid increasing population in Africa, more and more pressure is exerted on arable land. Therefore, many households are no longer able to live on agriculture alone but also engage in non-farm entrepreneurship activities-(Oseni and winters, 2009). There is mounting evidence that non-farm income (income derived from wage paying activities and self-employment in commerce, manufacturing and other services) is an important resource for farm and other rural households and urban residents (Lanjouw and Lanjouw, 2001). 
Women use their non-farm income to finance farm investments, to self insure or purchase cash inputs for agricultural production (Reardon et al, 1994; Ellis, 1998; Barret et al., 2001; Davies et al., 2002; Reardon et al, 2006). Oseni and Winters (2009) posited that the surplus cash generated from non-farm enterprise directly influences the purchase of agricultural inputs.

World Bank (2005) mentioned the significant roles women play in economic development. West African women play important role as farmers, traders and entrepreneurs, and these roles are of central importance to their families and the economy of West Africa. However, the degree of women participation in non-farm enterprise and farm enterprise varies according to customs in different regions and countries. In sub-Saharan Africa, women produce $80.0 \%$ of basic food stuffs. In Nigeria, women produce about $60.0 \%-80.0 \%$ of agricultural food in the country. They direct their earnings to meet the needs of their families. The rural women combine their roles as wives, mothers, housekeepers with their invaluable tasks as farmers, farm labourers, etc. They work longer hours at home and in farms using labour intensive and primitive farm implements for output and income generation (Nnonyelu, 1997).

Incentives and capacity for undertaking non-farm enterprise may diverge; thus resourceful poor women farmers may very well have strong incentives to participate in rural non-farm enterprise but lack the financial or technical capacity to do so because of various constraints. Incentives to participate in rural non-farm enterprise differ according to women's wealth (Escobal, 2001). Thus, decisions made by women concerning the farm and extent of their involvement in non-farm enterprise (either starting enterprise or entering the wage labour market) may be constrained due to inadequate capital and formal education (Oko, 2005).

In Nigeria, agriculture has historically been dominating the economy. The leading role of the agricultural sector was reflected earlier in government policies as development programs and intervention policies focus mainly on the agricultural sector. As observed in developing countries, most efforts of the local government to develop rural growth corresponded with policies focused solely to enhance farm productivity or increase employment in agriculture (Escobal, 2001; Woldenhanna, 2002).

Ikwuano L.G.A of Abia State is an agricultural as well as non-agricultural community. Women in the area are known to participate in both farm and non-farm enterprises. Any study aimed at improving their decision to engage in non-farm enterprises may also help to boost their farm income generation. Specifically the objectives of this study were to: (i) describe socio-economic characteristics of women farmers engaged in non-farm enterprise(s) in the study area; (ii) determine factors that influence women farmers' decision to embark on non-farm enterprise(s) in the study area and (iii) identify problems constraining women farmers from embarking on nonfarm enterprises in the study area. 


\section{Study Area}

\section{METHODOLOGY}

The study was carried out in Ikwuano Local Government Area (LGA) of Abia State. Ikwuano Local Government Area was created out of the defunct Umuahia L.G.A. on the $27^{\text {th }}$ of August 1991 and has its headquarters at Isiala Oboro. Ikwuano L.G.A. is located between latitudes $5^{\circ}$ $24^{1} \mathrm{~N}$ and $5^{\circ} 30^{1} \mathrm{~N}$ of the equator and longitudes $7^{\circ} 32^{1} \mathrm{E}$ and $3^{\circ} 37^{1} \mathrm{E}$ of the Greenwich Meridian. Ikwuano L.G.A has a population of 137,993 people which comprise of 61,945 males and 71,020 females (NPC, 2006). It has a land area of about 310 square kms and a population density of 194 person $/ \mathrm{km}$.

The major occupation of the people is farming. The major food crops grown are cassava, yam, melon, vegetable, three-leaf yam and cowpea. Some important cash crops grown in Ikwuano LGA are oil palm and cocoa, while animals reared are goats, sheep, pigs and poultry.

\section{Sampling Technique}

The population for this study was made up of women farmers in the study area. Three stage random sampling technique was used for this study. First, three autonomous communities (Amaoba Ime, Ariam Usaka-Ukwu and Oboro) were randomly selected from the twenty eight (28) autonomous communities in Ikwuano L.G.A. Four villages were randomly selected from each of the three communities, thus, giving a total of twelve villages. Lastly, ten women farmers were selected from each of the 12 villages to give a sample size of 120 respondents.

\section{Data Collection}

The data for this study were obtained from primary source. The primary data was obtained through the administration of a well structured questionnaire. The questionnaire was used to elicit information on selected socio-economic variables of the respondents. Secondary sources of information were collected from published and unpublished literatures such as journals, theses, newspapers, magazines, annual reports of some agricultural establishments, textbooks and the internet.

\section{Analytical Tools}

Objectives ( $\mathrm{i}$ and iii) were analyzed using descriptive statistics such as means, frequency distribution tables and percentages. Objective (iii) was analyzed using probit regression analysis.

\section{Model Specification}

The probit regression model is appropriate when the response takes one of only two possible values representing presence or absence. This is expressed as in Gujarati (2003).

$\left[\mathrm{F}_{\mathrm{Zi}}\right]$

Where

$z_{i}=\beta_{0}+\beta_{1} X_{i}$

$Y_{i}=\beta_{1}+\beta_{2} X_{2 i}+$ $+\beta_{k} X_{k i}+\mu$

$Y^{*}$ is unobserved but $Y_{i}=0$ if $\mathrm{yi}^{*}=1$ if $Y_{i}^{*} \geq 0$ 
$P\left(Y_{i}=1\right)=P\left(Y_{i}^{*} \geq 0\right)$

$P\left(\mu_{i} \geq-\beta_{1}-\beta_{2} X_{2 i} \ldots \ldots \ldots \ldots \ldots . . . \beta_{k} X_{k 1} \ldots\right.$

(3)

Where $\mathrm{i}=1,2 \ldots$ (120respondents)

Where $Y_{i}=$ women decision for non-farm enterprise.

(Dichotomous dependent variable $1=y e s, 0=$ No)

$\beta=A$ factor of unknown coefficients.

$x_{1}=$ age (years)

$x_{2}=$ level of education (years)

$x_{3}=$ farming experience (years)

$x_{4}=$ household size (number)

$x_{5}=$ educational level of spouse (years)

$x_{6}=$ type of non-farm enterprise (wage earning $=1$, others $=0$ )

$x_{7}=$ membership of cooperative society (member $=1$, otherwise $=0$ )

$\mathrm{X}_{8}=$ primary occupation (farming $=1$, otherwise $=0$ )

\section{RESULTS AND DISCUSSION}

\section{Socio Economic Characteristics of the Respondents}


Osondu 2014

Table 1:The Socio-Economic Distribution of the Women Farmers Engaged in Non-Farm Entrepreneurship in Abia State

\begin{tabular}{|c|c|c|}
\hline Socio-economic Variables & Frequency & Percentage \\
\hline \multicolumn{3}{|l|}{ Age (years) } \\
\hline $21-30$ & 47 & 39.16 \\
\hline $31-40$ & 37 & 30.83 \\
\hline $41-50$ & 27 & 22.50 \\
\hline Above 50 & 9 & 7.50 \\
\hline \multicolumn{3}{|l|}{ Mean: 35} \\
\hline \multicolumn{3}{|l|}{ Standard deviation: 9.37} \\
\hline \multicolumn{3}{|l|}{ Marital status } \\
\hline Single & 47 & 39.17 \\
\hline Married & 66 & 55.00 \\
\hline Widowed & 6 & 5.00 \\
\hline Divorced & 1 & 0.83 \\
\hline \multicolumn{3}{|l|}{ Household size } \\
\hline $1-4$ & 51 & 42.5 \\
\hline $5-8$ & 60 & 50.0 \\
\hline Above 8 & 9 & 7.5 \\
\hline Mean: 5 & 4.52 & \\
\hline Standard deviation: 3.23 & 3.23 & \\
\hline \multicolumn{3}{|l|}{ Educational Level } \\
\hline No formal Education & 9 & 7.50 \\
\hline Primary Education & 24 & 20.00 \\
\hline Secondary Education & 52 & 43.33 \\
\hline Tertiary Education & 35 & 29.17 \\
\hline \multicolumn{3}{|l|}{ Primary Occupation } \\
\hline Farming & 38 & 31.67 \\
\hline Public servant & 26 & 21.67 \\
\hline Traders & 42 & 35.00 \\
\hline Artisans & 14 & 11.67 \\
\hline \multicolumn{3}{|l|}{ Access to credit } \\
\hline Yes & 55 & 45.83 \\
\hline No & 65 & 54.17 \\
\hline Farm size (ha) & Frequency & Percentage \\
\hline$<1$ & 68 & 56.67 \\
\hline $1-2$ & 26 & 21.67 \\
\hline $3-4$ & 26 & 21.67 \\
\hline \multicolumn{3}{|l|}{ Years of farming experience } \\
\hline $1-10$ & 94 & 78.33 \\
\hline $11-20$ & 14 & 16.67 \\
\hline $21-30$ & 12 & 10.00 \\
\hline \multicolumn{3}{|l|}{ Mean: 8} \\
\hline \multicolumn{3}{|l|}{ Standard deviation: 6.94} \\
\hline Total & 120 & 100.00 \\
\hline
\end{tabular}

Source: Field survey data 2014 
The distribution of the women farmers according to socio-economic characteristics is shown in Table 1. From the Table it can be adduced that $39.16 \%$ of the women farmers were within the age range of $21-30$ years, while $30.83 \%, 22.50 \%$ and $9.75 \%$ of them were within the age range of 31-40 years, 41-50 years; and above 50 years respectively. This is an indication that the women in the study area were mostly middle aged entrepreneurs. The mean age of the women farmers was 34.92 years. The implication is that they are energetic and within the active productive work force. This finding refutes Davidson (1991) who inferred that increasing quest of an individual to be an entrepreneur stems from the general need of older individuals to earn additional income to support the cost of living (i.e., support domestic burden and pay for mortgage). However, it conforms to Miller (1984), who reports that younger people choose off-farm entrepreneurship as they are more energetic and more likely to combine farm and off-farm projects.

In terms of marital status, $55.0 \%$ of the women farmers were married, while $39.17 \%$ of them were single. Also, $5.0 \%$ and $0.8 \%$ of the respondents were widowed and divorced respectively. This means that the married women were more involved in off-farm entrepreneurship in the study. Married women are usually involved in off-farm business because of the need to supplement family means of livelihood (Anyiro and Emerole, 2013). However, married women with children may not be relieved of some filial responsibilities and may not therefore be able to devote more time to the day to day obligations of non-farm entrepreneurship.

Table 1 also shows the distribution of the women farmers according to household size. A moderate proportion $(50.0 \%)$ of the women farmers had household sizes of between $5-8$ members, while $42.5 \%$ and $7.5 \%$ of them had between $1-4$; and 9 and above persons respectively. The mean household size was 4.52 members. This result indicated that these respondents have moderate family sizes. This has implications on labour supply to the business. This may justify the need to augment family labour with hired labour. In the absence of wellfunctioning labour markets, smaller households face higher labour bottlenecks at critical points in their business (Ezeh et al., 2012; Osondu and Ibezim, 2013).

The Educational level of the women farmers in Abia State as displayed in Table 1 revealed that a fair proportion $(43.33 \%)$ of the women had secondary school education while $7.50 \%$ of them had no formal education. However, $92.50 \%$ of the women farmers in the study area were literate with divers' formal educational levels ranging from primary school education to tertiary education. Literacy (ability to read and write) would enable the women farmers to better utilize effectively and efficiently available resources in the area and curtail frivolous spending. As expected, higher education would enhance improved business ideas, skills, innovation and managerial ability for business sustainability. This result was in agreement with Nwibo and Okorie (2013) that as an individual increases his educational attainment, his entrepreneurial quest and skill increase, thus 
expanding his knowledge base which makes him alert to new opportunities, and increase the opportunity cost of being self-employed.

The distribution of the women farmers according to their primary occupation is shown in Table 1 .The Table shows that $35.00 \%$ of the women primary occupation was trading, $31.67 \%$ were farmers, $21.67 \%$ were public servants while $11.67 \%$ were artisans, this implies that, a good proportion $(68.33 \%)$ of the respondents' main sources of income were non-farm sources. This finding further highlighted the growing importance of the non-farm sector. Due to the rapid migration over the years from rural (farm sector) to urban centers (non-farm sector), the number of people who are engaged primarily on farming has declined (Osondu et al., 2013). According to them, the reason for this trend could be traceable to the difference in relative opportunity cost of labour in farm and non-farm sectors.

Table 1 shows that $45.83 \%$ of the women in the study area received credit for their off farm business enterprise while a good proportion (54.17\%) of them had no access to credit. Inadequate capital is a major problem confronting small-scale enterprises in Nigeria. However, lack of access to credit facilities constituted a constraint in purchasing raw materials and other enterprise inputs. Meanwhile, access to credit is regarded as one of the key elements in raising productivity (Anyiro and Oriaku, 2011).

The table shows that a good proportion (56.67\%) of the women farmers had farm size of less than 1 hectare, while $21.67 \%$ of them had farm land of between 1-2 hectares. The mean farm size of the respondents was 1.64 hectares. This was a clear indication that the women farmers in the area are mostly small scale farmers. This result which is quite a popular finding among previous studies (Abdulai and Delgado, 1999; Woldehanna and Oskam, 2001; Bedemo et al., 2013) confirms that rural households with small landholding and farm output which is the case among majority of women in the study area depend on the opportunities in the off-farm sector to escape poverty by supplementing income from the farm.

Table 1 further shows that $78.33 \%$ of the women farmers had farming experience of between 1 10 years. Also, $16.67 \%$ of the respondents had between $11-20$ years of farming experience, while $10.0 \%$ of them had farming experience of between $21-30$ years. The mean farming experience was 7.75 years. This indicated a relatively high farming experience in the study area. This could be explained by the fact that farmers who were highly experienced in farming and most likely older farmers were not very active economically to seek non-farm enterprise investment opportunities. They therefore prefered to depend on farming only (Korir et al., 2013) 


\section{The Factors Influencing Women Decision to Embark On Non-Farm Enterprises}

Table 2: Binary Probit Regression Coefficients of the Factors Influencing the Decision of Women Farmers for Entrepreneurship in off-farm Business Enterprises in Ikwuano LGA of Abia State, Nigeria

\begin{tabular}{lllll}
\hline Variable & $\begin{array}{l}\text { Estimated } \\
\text { coefficients }\end{array}$ & $\begin{array}{l}\text { Standard } \\
\text { errors }\end{array}$ & $Z$ & $P>|z|$
\end{tabular}

\begin{tabular}{lllll}
\hline Age & $-0.0261776^{*}$ & 0.0160744 & -1.67 & 0.103 \\
Educational level & 0.0045142 & 0.1693254 & 0.03 & 0.979 \\
Household size & $-0.1102986^{* *}$ & 0.0465268 & -2.37 & 0.018 \\
Spouse education level & -0.0934318 & 0.0708412 & -1.32 & 0.188 \\
Primary occupation & $-0.6358598^{* *}$ & 0.3001245 & -2.12 & 0.034 \\
Farm income & $0.2760421^{*}$ & 0.1498301 & 1.84 & 0.065 \\
Access to credit & $-0.5817876^{*}$ & 0.3889905 & -1.50 & 0.135 \\
Farming experience & $-0.715352^{* * *}$ & 0.1616211 & -4.43 & 0.000 \\
Type of enterprise & 0.1721623 & 0.283995 & 0.61 & 0.544 \\
Farm size & -0.0640065 & 0.1087731 & -0.59 & 0.556 \\
Cooperative society & $0.5326133^{*}$ & 0.2761284 & 1.93 & 0.054
\end{tabular}

Number of observations at one: 80

Number of observations at zero: 40

Log likelihood: -62.333253

Wald chi2 $=66.39$

Cases predicted correctly (\%): 69.6

Pseudo R2: 0.1504

Source: Field survey data, 2014.

* Significant at $10 \%$ level

** Significant at $5 \%$ level

*** Significant at $1 \%$ level

The probit regression model of the factors influencing women's decision to embark on non-farm enterprises in Abia State Nigeria is presented in Table 2. Overall, the model predicted 69.64 percent of the sample correctly and posted a log likelihood value of -62.33 and a goodness of fit chi-square value of 66.39 which was statistically significant at $1 \%$ level.

In the model, seven out of eleven explanatory variables were statistically significant at given levels and these were the coefficient of age, farming experience, access to credit, farm income, household size primary occupation and membership of cooperative society. The positive sign on the variable's coefficient indicates that higher values of the variable increase women's decision to embark on non-farm enterprises. 
Specifically, the coefficient (-0.0261776) of age was negative and statistically significant at $90.0 \%$ confidence level. The sign is not in conformity with a priori expectation. This implies that age has an indirect influence on the decision of the women farmers to embark on entrepreneurship. In offfarm enterprise increase in age of an entrepreneur decreases her desire and quest to be an entrepreneur. This finding refuted Davidson (1991) who inferrs that increasing quest of an individual to be an entrepreneur stems from the general need of older individuals to earn additional income to support the cost of living (support domestic burden and pay for mortgage). However, this result conformed to Miller (1984), who reports that younger people choose entrepreneurship as they are more likely to enter riskier projects. Ibrahim and Srinivasan (2013) support this assertion that rural households' likelihood to participation in off-farm activities decreases as they grow older. This outcome may be due to the fact that older women are more rigid and have lesser flexibility to enhance their participation in off-farm enterprises.

The coefficient of household size to $(-0.1102986)$ was significant at $5.0 \%$ alpha level and had a negative effect on women farmers' decision to embark on off-farm entrepreneurship. Unlike alternative off-farm activities, majority of the self- employment activities were managed by the household heads and require more of starting capital and entrepreneurial experience than additional labour made possible by the increase in household size. Also, the availability of the members of the extended family which is the case in most rural households in Nigeria, provides the extra care and attention needed for the additional number of dependants, hence was not surprising that, it had negative effect on decision for off-farm enterprises. This result is dissimilar to the one obtained by Bedemo, et al., (2013) who reported that household composition has an insignificant effect on farmers' decision to embark on entrepreneurship in off-farm enterprises.

The coefficient of primary occupation $(-0.6358598)$ was negative and statistically significant at $5.0 \%$ probability level. The sign of the variable is in tandem with a priori expectation. The implication is that being a farmer (farming as primary occupation) will reduce entrepreneurship decision for off-farm enterprises. Women who are primarily involved in farming activity devote their time to this activity, hence less likely to engage in non-farm enterprise activities. This study found that the prevalent types of non-farm enterprises in the study area required direct day to day running of the business and might be difficult for the women farmers to combine both enterprises, hence may not stir decision to embark on off-farm enterprises. This result is not quite a popular finding among previous studies (Abdulai and Delgado, 1999; Woldehanna and Oskam, 2001; Bedemo et al., 2013) that rural women farmers with small landholding and farm output which is the case among majority of women in Nigeria depend on the opportunities in the off-farm sector to escape poverty by supplementing income from farming.

The coefficient $(0.2760421)$ of farm income per capita was significant and positive. The marginal effect value for farm income per capita was statistically significant at the $1.0 \%$ level. This implies 
that an increase in farm income of the women farmers will stir up their decision to embark on nonfarm enterprises. This corroborated Bohacek (2006) who inferrs that wealth possessed by the individuals provides a degree of security for entering self-employment and helps them to ease their credit constraints. Thus, women with higher levels of income have a higher tolerance for risks. Hence, they are most likely to be business owners. Limited financial resources at the disposal of women farmers act as barriers to entry into non-farm enterprise investments. The fact that farm income determines participation in non-farm entrepreneurship implies that entry into lucrative non-farm enterprises could be more difficult for the poor households with little income. This could increase inequality where the poor are exposed to higher risks due to dependence on limited sources of income. This outcome echoed the findings of Oseni and Winters (2009) who reports in their studies in Nigeria that households with increased farm income are more likely to diversify in off-farm income generating activities, hence undertake off-farm work.

Contrary to a priori expectation, the coefficient of access to credit (-0.5817876) was significant at $10.0 \%$ alpha level of probability and had a negative effect on women farmers' decision to embark on off-farm entrepreneurship. The sign of the variable is at variance with normal expectation. It implies that women farmers' decision of taking entrepreneurship in off farm enterprise decreases with access to credit. The result was not in agreement with by Barret et al., (2001), who reported that households with access to credit facilities would more likely diversify outside agriculture to reduce risks. The result revealed that women farmers in the study area might have spent most of their sourced credit on consumption and investment in farm related activities, rather than off farm entrepreneurship.

The coefficient $(-0.715352)$ of years of experience in farming had a statistically significant and negative effect on the probability of embarking on non-farm enterprise. This suggests that engagements in non-farm enterprises are easy for women farmers within some range of years of experience in farming, beyond which this engagement reduces. This could be explained by the fact that women farmers who are highly experienced in farming, tend to invest more of their time and financial resources in it. Hence, they have little or no resource to invest in off-farm enterprises. They therefore preferred to depend on farming only. Thus implying that as individuals increase their farming experience through training and learning, their quest to be an entrepreneur decreases. This affirmed the earlier finding of Bosma, et al., (2009) who deduce that having had experience in a particular sector increases the probabilities of becoming an entrepreneur in such enterprise. The marginal effect value for years of experience in farming was statistically significant at $1.0 \%$ significance level.

Membership of cooperative society gave a positive coefficient $(0.5326133)$ and was significant at $10.0 \%$ alpha level, indicating that being a member of cooperative society increased probability for entrepreneurship decision in off-farm enterprises among the women farmers. The sign identity of this variable conforms to a priori expectation. This presupposed that membership of cooperative 
society aids in receiving and evaluating information for business improvement and productivity (Ajagbe et al., 2007).

\section{The Women Farmers' Constraints in Embarking on Non-farm Enterprises}

Table 3: The Constraints of Decision to Embark on Non-Farm Entrepreneurship in Abia State

\begin{tabular}{lll}
\hline Constraints & Frequency $^{*}$ & Percentage \\
\hline Inadequate capital to start up non-farm business & 52 & 43.33 \\
Lack of access to credit & 42 & 35.00 \\
Identification of off-farm business-enterprise & 27 & 22.50 \\
Land procurement issues & 38 & 31.67 \\
Water availability & 25 & 20.83 \\
Inadequate electricity & 31 & 25.83 \\
inadequate reliable public transport/roads & 38 & 31.67 \\
\hline
\end{tabular}

Source: Field survey data, 2014

${ }^{*}$ Multiple responses recorded

Table 3 shows the constraints hindering women from embarking on non-farm enterprises in Abia State. The Table reveals that inadequate start-up capital (43.33\%) was the major constraint that has militated against women from embarking on non-farm enterprises in the study area. Other serious constraint identified by the respondents is lack of access to credit (35.0\%). Access to credit has been identified as serious in off-farm business sector start up especially in the case of self-employment activities in developing economies like Nigeria where the credit market is undeveloped. Land procurement issue was identified (31.67\%) as a problem facing women in off-farm business. Access to land is still mediated via patrilineal systems (Aluko and Amidu, 2006), in spite of the intentions of the 1978 Land Use Act. User rights often follow marriage and inheritance or borrowing. Land access is severely curtailed by the way land is inherited, owned and passed on by men to their male descendants in most patrilineal ethnic groups, especially in eastern Nigeria. The table also revealed that $22.5 \%$ of the women complained of Identification of off-farm business-enterprises, while others complained of inadequate social amenities such as electricity (25.83\%), water (20.83) and inadequate reliable public transport/roads $(31.67 \%)$ as constraints.

In fact, there is a strong case for arguing that without capital, credit and complementing public infrastructure (roads, bridges, electricity, water), it is difficult to see how women farmers could diversify to non-farm enterprises and generate income that can sustain an adequate livelihood (Durno and Stuart 2005; Hoddinott, 1998; Anyiro and Oriaku, 2011; Ezeh et al., 2012). 


\section{CONCLUSIONS AND RECOMMENDATIONS}

From the study, it was revealed that age, household size, primary occupation, farm income, access to credit, farming experience and membership of cooperative society had a significant influence at varied levels and signs on women farmers' decision to embark on non-farm enterprise.

Based on principal findings of this study, the following recommendations were made: (i) individual women farmers should be advised and encouraged to form and or join co-operative societies so as to be better positioned to receive credit and evaluate business improvement and productivity information; (ii) and the persistent land procurement problem faced by women in Nigeria calls for full implementation of the Land use Act of 1978, which will enable women farmers generate more income that could be used to start up non-farm businesses.

\section{REFERENCES}

Abdulai, A., and Delgado, C. L. (1999). Determinants of Nonfarm Earnings of Farm Based Husbands and Wives in Northern Ghana. American Journal of Agricultural Economics. 81(1): 117-130.

Ajagbe, F.A, Adewoye, J.O. and Ajetomobi, J.O. (2007). An Evaluation of Financial Performance of Community Banks in Ogbomoso Area of Oyo State, Nigeria. International Business Management,.1 (4): 65-69.

Aluko, B.T., and Amidu, A. (2006) Women and Land Rights Reforms in Nigeria. Paper presented at 5th FIG regional conference, on Promoting Land Administration and Good Governance. Accra, Ghana.

Anyiro C.O. and Emerole C.O (2013). Income generation activities and poverty alleviation strategies of rural women farm households in Abia State, Nigeria. Paper presented at the $47^{\text {th }}$ annual conference of Agricultural Society of Nigeria (ASN) held at the Federal College of Animal Health and Production Technology, Moor Plantation, Ibadan from $4^{\text {th }}-8^{\text {th }}$ November, 2013.

Anyiro, C.O. and B.N. Oriaku (2011). Access to and Investment of Formal Micro Credit by small Holder Farmers in Abia State, Nigeria. A case study of ABSU Micro Finance Bank, Uturu. The Journal of Agricultural Sciences, Faculty of Agricultural Sciences of the Sabaragamuwa University of Sri Lanka, 6 (2): 69-76.

Barrett, C. B, Reardon, T. and Webb, P. (2001). Non-farm Income Diversification and Household Livelihood Strategies in Rural Africa: Concepts, Dynamics, and Policy Implications, Food Policy 26 (2): 315-331.

Bedemo, A. Getnet, K. Kassa, B. and Chaurasia S.P.R. (2013). Off-farm Labor Supply decision of Adults in rural Ethiopia: Double hurdle Approach. Journal of Agricultural Economics and Development. 2(4):154-165.

Bohacek, R. (2006). Financial Constraints and Entrepreneurial Investment. Journal of Monetary Economics. 53 (8): 2195-2212.

Bosma, N.S., Acs, Z. J., Autio, E., Coduras, A., and Levie. J. (2009). Entrepreneurship Education and Training. Global Entrepreneurship Monitor. 2: 5 - 11.

Davidson, P. (1991). Continued Entrepreneurship: Ability, need, and opportunity as determinants of small firm growth. Journal of Business Venturing. 6 (6): 405- 429.

Davies, B, Reardon, T. Stamoulis, K. and Winters, $P$ (2002) promoting farm/non-farm linkages for rural development: case studies from African and Latin America. FAQ, Rome. 196. 
Durno, J., and Stuart, R. (2005). Gender issues in sustainable agriculture. In Gender roles in development projects (ed.) Overholt C. New Delhi Fox Publisher, New Delhi, India.24-37

Ellis, F. (1998). Household strategies and rural livelihood diversification. Journal of Development Studies, 35: 1-38.

Escobal, J. (2001). The determinants of non-farm income diversification in rural Peru. World Development,29:497-508.

Ezeh, C. I. Anyiro, C.O. and Chukwu, J. A. (2012). Technical Efficiency in Poultry Broiler Production in Umuahia Capital Territory of Abia State, Nigeria. Greener Journal of Agricultural Sciences, 2 (1): 001-007.

Hoddinott, S.A. (1998) "Implementation of the Poverty Alleviation Programme: Lilongwe, Malawi MIT press. 12 pp.

Ibrahim, M.K .and Srinivasan, C.S. (2013). Off-farm Labour Supply Decision of Households in Rural Nigeria: A Double hurdle model Approach. Department of Agriculture and Food Economics University of Reading, Reading, United Kingdom.

Korir, L.K. Lagat, J.K. and Njehia, B.K. (2013). Farm households' livelihood diversification and its implications for young people's Engagement in agriculture, the case of Uasin Gishu County, Kenya. Department of Agricultural Economics, Egerton University, Egerton, Kenya.

Lanjouw,J.O and Lanjouw,p.(2001). The Rural Non-farm Sector: Issues and Evidence from Developing Countries. Agricultural Economics. 26:1-23.

Miller, R. (1984). Job Matching and Occupational Choice. Journal of Political Economy. 92: 1086-120.

National Population Commission (NPC), (2006). The Population Census of the Federal Republic of Nigeria Analytical report at the National Population Commission- Abuja.

Nnoyelu, C. (1997). An appraisal study of the agricultural extension system in Nigeria. The role of women in: The Nigerian Agricultural Research Strategy Plan and Extension Delivery: Policy Concept and consensus to the year 2010 (eds) Adedipe, N.O. Bakshi, J.S. and Aliyu, A. 389 - 392.

Nwibo, S U. and Okorie, A. (2013). Determinants of Entrepreneurship Among Agribusiness Investors In SouthEast, Nigeria. European Journal of Business and Management. 5(10): 115-123.

Oko, O.O. (2005). Women in rural development: the Nigerian experience In: Agricultural Extension and Rural Sociology (eds) Nwachukwu, I. and Onekwusi, G. Snap press Ltd. 229-238.

Oseni G. and Winters, P. (2009). Rural Nonfarm Activities and Agricultural Crop Production in Nigeria. Agricultural Economics, 40 (2): 198-201.

Osondu, C.K. Anyiro, C.O. And Emerole, C.O. (2013) Migrant Ages and Determinants of Household Labour Supplies in Food Crop Production in Ikwuano Abia State, Nigeria. World Research Journal of Tropical Agriculture.

1 (2): 31-35.

Osondu, C.K. and Ibezim G.M.C. (2013) Determinants of Rural-Urban Migration and its effect on Rural Farm Labour availability in Umuahia North Local Government Area of Abia State, Nigeria. Research WebPub. 1(3): 29-35.

Reardon, T. Crawford, E. and Ketty, V. (1994). Links between non-farm income and farm investments in African households. Adding the capital market perspective. American Journal of Agricultural Economics, 74:1172-1176 
Reardon, T, Berdegue, J. Barret, C.B. and Stamoulis, K. (2006). Household Income Diversification into Rural non-farm activities. In: Transforming the Rural non-farm Economy(eds) Haggbiade, S, Hazell, P, Reardon T Baltimore, USA, John Hopkins University Press, M.0, 115-141.

Woldenhanna, T. (2002). Rural farm/non-farm income linkages in Northern Ethiopia. In: Promoting Farm/nonfarm linkage for Rural Development, case study of Africa and Latin America.(eds) Davies, B, Reardon, T, Stamoulis, K, Winters, Rome, FAQ, 121-144.

Woldenhanna, T. and Oskam, A. (2001). Income Diversification and Entry Barriers: Evidence from the Tigray Region of Northern Ethiopia. Food Policy, 26(4): 351- 365.

World Bank (2005).Status of gender equality and situation of women in Nigeria patriarchy (in) national gender policy $3 \mathrm{pp}$. 